\title{
A Historical Analysis of Rainfall Trend in the Olifants Basin in South Africa
}

\author{
C. Gyamfi ${ }^{1,2}$, J. M. Ndambuki ${ }^{1} \&$ R. W. Salim ${ }^{1}$ \\ ${ }^{1}$ Department of Civil Engineering, Tshwane University of Technology, Pretoria, South Africa \\ ${ }^{2}$ School of Bio-resources Engineering, Anglican University College of Technology, Nkoranza, Ghana \\ Correspondence: Charles Gyamfi, Civil Engineering Department, Tshwane University of Technology, Pretoria, \\ South Africa. Tel: 27-08-3433-5917/ 2330-2432-12413. E-mail: gyamficharles84@yahoo.com
}

Received: December 3, 2015

Accepted: December 18, 2015

Online Published: January 31, 2016

doi:10.5539/esr.v5n1p129

URL: http://dx.doi.org/10.5539/esr.v5n1p129

\begin{abstract}
A set of homogeneity test methods and the Mann-Kendall trend test were applied on historical rainfall records of the Olifants Basin to detect changes in rainfall pattern under a changing climate. In total, historical rainfall records from 13 stations obtained from the South African Weather Service (SAWS) and the Department of Water Affairs (DWA) spanning the period 1975-2013 were used in the analysis. Results of the study indicate an insignificant declining rainfall trend in the Olifants Basin with a mean annual rainfall of $664 \mathrm{~mm}$. Rainfall in the basin exhibits spatio-temporal variation with coefficient of variation of $24 \%$. Inter-annual and seasonal variability is dominant in the records examined. Changes observed in rainfall over the years were therefore concluded to have resulted due to climate change impacts.
\end{abstract}

Keywords: climate change, homogeneity, mann-kendall test, olifants basin

\section{Introduction}

Over the years the burgeoning issues of global warming and climate change have increasingly gained global attention owing to their devastating impacts on water resources, ecosystem services and livelihoods (Barnett \& Adger, 2007; NRDC, 2010; IPCC, 2014). These repercussions of climate change have ignited within the global scientific community the need to seek relevant solutions through the application of state of the art technologies to alleviate the consequences thereof. Some of these investigations can be recounted in the recent works carried out by Haddeland et al. (2014) and Prudhomme et al. (2014). In their study, Haddeland et al. (2014) assessed at the global scale the current and future water availability and consumption patterns employing ensemble models. In the same vain, Prudhomme et al. (2014) used multimodel ensemble tools to investigate the hydrological droughts in the $21^{\text {st }}$ century. In China, Piao et al. (2010) applied models to examine the impacts of climate change on water resources and agriculture. Christensen and Lettenmaier (2007) on the Colorado River Basin also employed multimodel ensemble methods in the assessment of climate change impacts on the basin's hydrology and water resources. Valipour in different studies (Valipour, 2012; 2013a, b; 2015) also demonstrated the potential threats on water resources that may arise due to changes in climatic variables. Fundamental to all these studies is the use of climatological data as forcing variables. Although these models come in handy and gives a vivid picture of the existing scenario at any point in time, it must be reiterated that the behavioral pattern of the key climatological variables used in forcing these models be understood to ensure a better interpretation of the model results.

Again, in using measured climatological data the homogeneity or inhomogeneity nature of the data should be verified. A climatic series is said to be "homogenous" when variations recorded in the time series are truly due to climatic variations (Lazaro et al., 2001) but not due to measurement errors or conditions around observation sites (Kang \& Yusof, 2012). When the converse happens, data is said to be "inhomogeneous" with variations in data attributed in part to the methods of measurement and inaccuracies of measuring instruments (Dhorde \& Zarenistanak, 2013). Use of climatological variables therefore calls for a pre-screening process to ensure the selection of homogenous data for climate change studies. This will give rise to confidence in model results as the variations observed will only be explainable by the variations in climate but not due to human and measurement errors encountered in data measurements.

To aid in this, we present in this work a behavioral examination through (i) homogeneity analysis and (ii) trend 
analysis on one of the key climatological variables - rainfall. Spatio-temporal changes of this variable have also been detailed. Our choice for the selection of this climatological variable for detailed analysis hinges on the fact that it is the single most important variable that ensures the availability of water on earth through the hydrologic cycle and as result knowledge in its change patterns is deemed essential in the midst of ensuring water security in a changing climate. It is also the case that this variable over the years has been the focus of many other studies (Zhang et al., 2000; Gong et al., 2004; Modarres \& da Silva, 2007; Karmeshu, 2012; Santosh \& Ramesh, 2013) thus contributing to the holistic understanding of the consequences of climate change. This investigation also seeks to add to the already existing body of knowledge on rainfall pattern variation whiles drawing on conclusions that are relevant to the atmospheric science community. The methods applied herein are applicable to other climatological variables and hence can be seen as a guide to examine other variables. The methods are also quick and robust in providing an overview in the wake of climate change assessment.

\section{Materials and Methods}

\subsection{Description of Study Area}

A semi-arid catchment; the Olifants Basin (Figure 1) in South Africa was used as the case study. The basin spans between latitudes $23.8^{\circ} \mathrm{S}$ and $26.5^{\circ} \mathrm{S}$ and longitudes $28.3^{\circ} \mathrm{E}$ and $31.9^{\circ} \mathrm{E}$ traversing three provinces in South Africa namely, Gauteng, Mpumalanga and Limpopo. The main stem of the Olifants River is approximately 770 $\mathrm{km}$ in length draining total land surface area of $54,308 \mathrm{~km}^{2}$ (Schultz \& Watson, 2002). The River has its source from Trichardt to the east of Johannesburg in the province of Gauteng and then flows in north-easterly direction through the provinces of Mpumalanga and Limpopo. The Olifant River crosses the Mozambique border and flows into the Massingire dam. The main tributaries of the Olifant are the Wilge, Moses, Elands and Ga-Selati rivers on the left bank and Klein Olifant, Steelpoort and Blyde rivers on the right bank (IWMI, 2008). On the right bank, steelpoort is the largest tributary draining an area of 7, $136 \mathrm{~km}^{2}$ compared to the Elands on the left bank with a drainage area of $6,148 \mathrm{~km}^{2}$. Generally, the elevation of the basin ranges from $0-2400$ meters above mean sea level (masl).

Climatically, the basin is characterized by the movement of air masses that is known to be associated with Inter-Tropical Convergence Zone (ITCZ). In summer, temperatures range from a minimum of $18^{\circ} \mathrm{C}$ to a maximum of $34^{\circ} \mathrm{C}$ whereas in Winter temperatures ranges from $5^{\circ} \mathrm{C}$ to $26^{\circ} \mathrm{C}$ (IWMI, 2008). Rainfall is seasonal in the basin, occurring during the months of October to April with appreciable spatio-temporal variability. The mean annual precipitation (MAP) is documented by Schulze et al. (1997) to be $630 \mathrm{~mm}$ with peaks in January.

Socio-economic activities in the basin include agriculture, mining industries, metallurgic activities and the presence of power generating plants. Agriculture forms the dominant economic sector with the main focus areas being commercial, temporary and subsistence cultivations. The proportion of gross domestic product (GDP) of South Africa obtained from the basin is estimated at 5\% (Department of Water Affairs and Forestry [DWAF], 2004). 


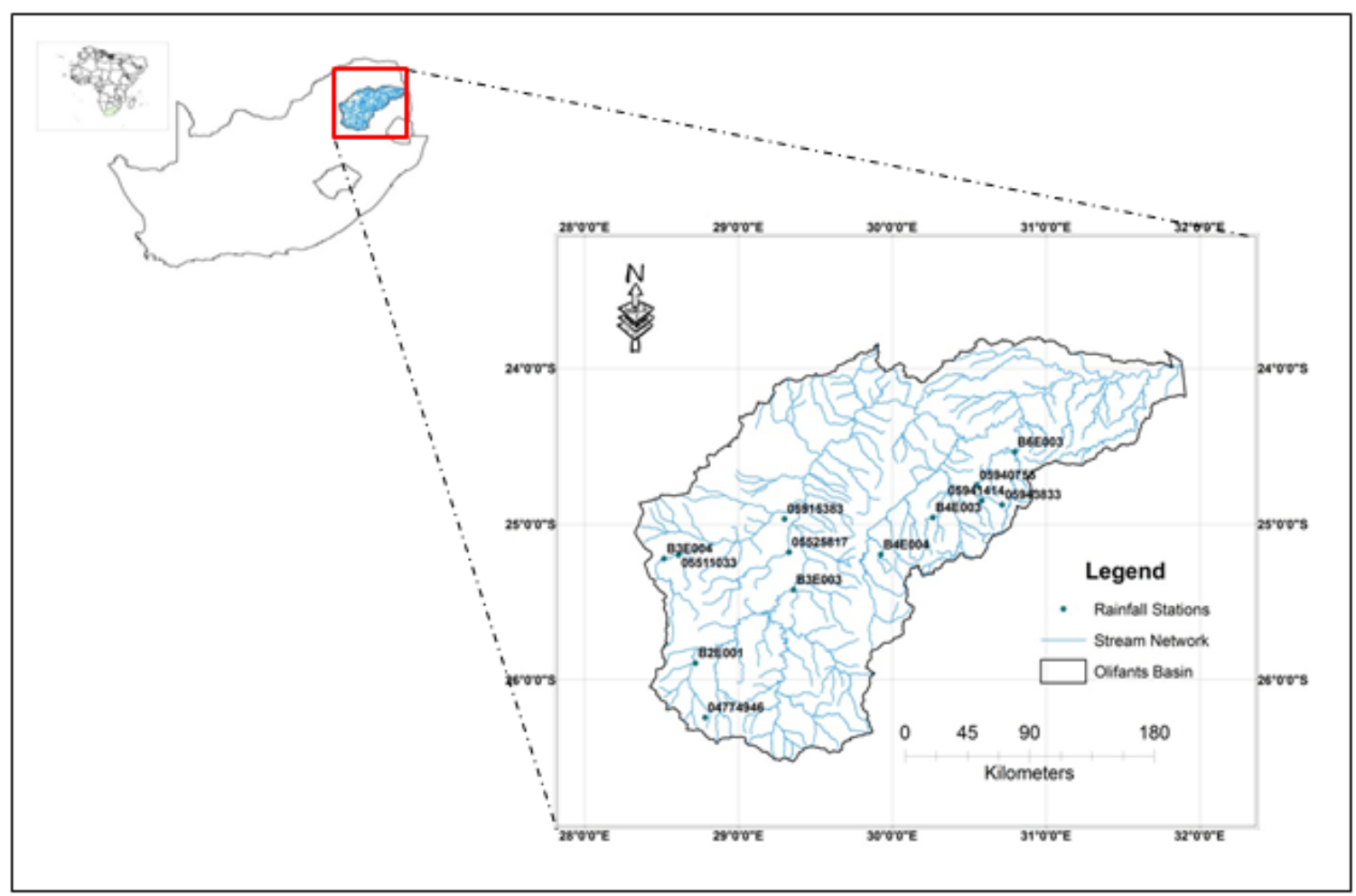

Figure 1. Map of the study area within the South African context showing meteorological stations

\subsection{Data Sources and Statistical Techniques}

\subsubsection{Meteorological Data}

In South Africa, climatological variables are measured and hosted by the South African Weather Service (SAWS). From this agency, rainfall data on a monthly and yearly time step for all meteorological stations within the case study catchment were acquired and analyzed for acceptability for use in the study. Historical rainfall data from stations maintained by the Department of Water Affairs (DWA) were also obtained to augment the data from SAWS. Station by station analysis of the historical records revealed gaps in almost all of the records available. In view of this, all stations with less than $10 \%$ of missing data were considered acceptable and were used in the study (Kang \& Yusof, 2012). The set criteria aimed at reducing uncertainty pose by limited time series data. This resulted in the final selection of 13 meteorological stations with data spanning the period 1975- 2013 and whose percentage missing data are presented in Table 1 . Stations with missing records were patched by replacing with the average of the previous and next value. The selected stations well represented the climatic conditions of the Olifants Basin with the stations fairly distributed in the study catchment (Figure 1).

Table 1. Selected stations and their percentage missing records for rainfall (1975-2013)

\begin{tabular}{lccc}
\hline \multicolumn{1}{c}{ Station Name } & Data ID & Missing data (\%) & Source \\
\hline Delmas Vlakplaas & 04774946 & 0.00 & SAWS \\
Morgenzon & 05943833 & 0.03 & SAWS \\
Rus-de-winter & 05511033 & 0.41 & SAWS \\
Rustplaats & 05941414 & 0.46 & SAWS \\
Marble Hall & 05915383 & 0.65 & SAWS \\
Ohrigstad & 05940755 & 0.67 & SAWS \\
Oudestad & 05525817 & 3.88 & SAWS \\
Loskop & B3E003 & 1.92 & DWA \\
Rus-de-winter & B3E004 & 4.30 & DWA \\
Roossenekal & B4E004 & 4.49 & DWA \\
Buffelskloof & B4E003 & 5.30 & DWA \\
Blyderiv & B6E003 & 8.99 & DWA \\
\hline
\end{tabular}




\subsubsection{Statistical Methods for Homogeneity Testing}

Homogeneity test is important in verifying the variability or otherwise of time series data. To test for the case of homogeneity in rainfall time series, this study employed four methods namely the Pettitt test, the standard normal homogeneity test (SNHT), the Buishands range (BR) test and von Neumann's ratio (VNR) for comparison purposes. Fundamental to the Pettit, SNHT and BR tests is the null hypothesis $\left(H_{0}\right)$ that the annual values $X_{i}$ of the variable $X$ under investigation are independent and identically distributed. The alternative hypothesis $\left(H_{l}\right)$ stipulates a step wise shift (break) in the variable $\mathrm{X}$. All tests were conducted at significance level of 0.05 (Nasri \& Modarres, 2009; Patra et al., 2012). Following are brief discussions on the mathematical concepts underlying each of the four methods.

\section{Pettitt Test}

The non-parametric Pettitt test postulated by Pettitt (1979) is used because is sensitive to breaks in the middle of time series data (Wijngaard et al., 2003; Costa \& Soares, 2009). In using this method, a test statistic $U_{k}$ is first estimated using equation 1 and then followed by the determination of the statistical change point (SCP) given by equation 2 and finally the determination of the critical value obtained through equation 3.

$$
\begin{gathered}
\mathrm{U}_{\mathrm{K}}=2 \sum_{\mathrm{i}=0}^{\mathrm{n}}\left[\mathrm{m}_{\mathrm{i}}-\mathrm{k}(\mathrm{n}+1)\right] \\
\mathrm{K}=\max _{1 \leq \mathrm{k} \leq \mathrm{n}}\left|\mathrm{U}_{\mathrm{K}}\right| \\
K_{c}=\sqrt{\left[-\ln \alpha \frac{\left(n^{3}+n^{2}\right)}{6}\right]}
\end{gathered}
$$

Where $m_{i}$ is the rank of the $i$-th observation when the values of the variable $x_{1}, x_{2} \ldots x_{n}$ in the series are arranged in ascending order, $\mathrm{k}=1,2, \ldots, . . \mathrm{n}$.

\section{Standard Normal Homogeneity Test (SNHT)}

Alexandersson (1986) propounded this method by comparing a statistical measure $\mathrm{T}(\mathrm{k})$ to the mean of the first $\mathrm{k}$ years with the last of $(\mathrm{n}-\mathrm{k})$ years. Theoretical represented as;

With $\overline{z_{1}}$ and $\overline{z_{2}}$ given by;

$$
\mathrm{T}_{\mathrm{k}}=\mathrm{k} \overline{\mathrm{z}_{1}}+(\mathrm{n}-\mathrm{k}) \overline{\mathrm{z}_{2}}, \quad \mathrm{k}=1,2, \ldots \mathrm{n}
$$

$$
\begin{gathered}
\overline{\mathrm{z}_{1}}=\frac{1}{\mathrm{k}} \sum_{\mathrm{i}=1}^{\mathrm{n}} \frac{\mathrm{X}_{\mathrm{i}}-\overline{\mathrm{X}}}{\mathrm{s}} \\
\overline{\mathrm{z}_{2}}=\frac{1}{\mathrm{n}-\mathrm{k}} \sum_{\mathrm{i}=\mathrm{k}+1}^{\mathrm{n}} \frac{\mathrm{X}_{\mathrm{i}}-\overline{\mathrm{X}}}{\mathrm{s}}
\end{gathered}
$$

To reject the null hypothesis of homogeneity (i.e. to accept the alternative hypothesis of non-homogeneity), the test statistic $T_{0}$, should satisfy equation 7 and should be larger than a certain critical value at a given significance level.

$$
\mathrm{T}_{0}=\max _{1 \leq \mathrm{k} \leq \mathrm{n}} \mathrm{T}_{\mathrm{k}}
$$

\section{Buishands Range (BR) Test}

Buishand (1982) established some equations referred to in here as the Buishand range method. The method is based on adjusted partial sum defined as;

$$
\mathrm{S}_{0}=0
$$




$$
S_{y}=\sum_{i=1}^{y}\left(Y_{i}-\bar{Y}\right), y=1,2, \ldots, n
$$

A rescale adjusted range, $R$ is estimated upon determination of Sy and given as

$$
R=\frac{\max _{0 \leq y \leq n} S_{y}-\min _{0 \leq y \leq n} S_{y}}{S}
$$

\section{Von Neumann Ratio Test}

The von Neumann test expresses the ratio of mean square successive difference to the variance and given as;

$$
N=\frac{\sum_{i=1}^{n-1}\left(Y_{i}-Y_{i+1}\right)^{2}}{\sum_{i=1}^{n}\left(Y_{i}-\bar{Y}\right)^{2}}
$$

\subsubsection{Classification of Homogeneity Results}

In order to assess the usefulness of the climatic data based on the homogeneity results, a classification system consisting of three main classes was adopted (Schonwiese \& Rapp, 1997; Wijngaard et al., 2003) at the 0.05 significance level. The respective criteria used in categorizing the rainfall time series into each of the classes are;

Class 1: Time series that falls within this class are considered "useful" and have to satisfy the condition of rejecting only one or none of the null hypothesis for the four tests under consideration. Time series under this category indicates the apparent absence of inhomogeneity. Trend and variability analysis can be executed using time series data that falls in this category.

Class 2: Under this class, the null hypothesis for two out of the four tests should be rejected and the series described as "doubtful". Although there is the indication of the presence of inhomogeneity, time series data that is captured under this class can be used in trend and variability analysis. However, care is required to execute this analysis in the purview of the existence of inhomogeneity.

Class 3: Class 3 which is described as "suspect" occurs when three or all the four tests reject the null hypothesis of a time series data. This indicates a clear presence of inhomogeneity and hence time series data in this category is discarded and not use for trend and time series variability analysis.

Following these classifications, climatic stations with time series data falling under class 1 and 2 were further used in trend and variability analysis.

\subsection{Trend Analysis}

From the homogeneity test results, climatic stations that satisfied the homogeneity condition were selected for trend analysis. Annual and seasonal trends were explored. Autumn, spring and summer seasons corresponding to monthly periods of March - May, September - November and December -February respectively were used in the seasonal trend analysis. The winter season (June-August) was not included in the seasonal analysis due to the little or no rain during this time period. The non-parametric Mann-Kendall (MK) test which is based on the null hypothesis $\left(\mathrm{H}_{0}\right)$ of the absence of a trend as opposed to the alternative hypothesis $\left(\mathrm{H}_{1}\right)$ of the presence of a trend was used in the trend detection analysis. This method is preferred and highly recommended by the World Meteorological Organisation (WMO) for trend detection analysis (Mourato et al., 2010) due to the advantage it offers in its applicability irrespective of the data distribution function present in the time series data (Smith, 2000; Mourato et al., 2010). The MK test is briefly discussed herein but one is referred to Mann (1945) and Kendall (1948) for further details on the method. The MK test is based on the test statistic S and computed as the difference between later measured values and earlier measured values, $\left(\mathrm{x}_{\mathrm{j}}-\mathrm{x}_{\mathrm{i}}\right)$ where $\mathrm{j}>\mathrm{i}$. The estimated difference is assigned an integer value of $1,0,-1$ indicating positive difference, no difference and negative difference respectively. The Mann-Kendall statistic on a series $\mathrm{x}_{1}, \mathrm{x}_{2}, \ldots \mathrm{x}_{\mathrm{n}}$ is given by;

$$
S=\sum_{i=1}^{n-1} \sum_{j=i+1}^{n} \operatorname{sgn}\left(x_{j}-x_{i}\right) \approx S=\sum_{i=1}^{n-1} \sum_{j=i+1}^{n} \operatorname{sgn}(\theta)
$$

where $\operatorname{Sgn}(\theta)$ satisfies any of the following conditions;

$$
\operatorname{Sgn}(\theta)=\left\{\begin{array}{c}
1 \text { if } \theta>0 \\
0 \quad \text { if } \theta=0 \\
-1 \quad \text { if } \theta<0
\end{array}\right.
$$


with $x_{j}$ and $x_{i}$ being sequential data values, $n$ is the length of data set.

When the data points, $\mathrm{n}$ satisfies the condition of $n \geq 8$, then the test statistic $\mathrm{S}$ is approximately normally distributed with the mean and variance given as;

$$
\begin{gathered}
\mathrm{E}(\mathrm{S})=0 \\
V(S)=\frac{n(n-1)(2 n+5)-\sum_{i=1}^{n} t_{i} i(i-1)(2 i+5)}{18}
\end{gathered}
$$

where $t_{i}$ is the number of ties of extent $i$.

The standardized test statistics $Z_{\mathrm{mk}}$ is eventually computed as;

$$
Z_{m k}=\left\{\begin{array}{cc}
\frac{S-1}{\sqrt{\operatorname{Var}(S)}} & S>0 \\
0 & S=0 \\
\frac{S+1}{\sqrt{\operatorname{Var}(S)}} & S<0
\end{array}\right.
$$

The standardized test statistics $Z_{\mathrm{mk}}$ therefore gives a measure of the significance of the trend. The null hypothesis is rejected if $\left|Z_{m k}\right|>Z_{1-\alpha / 2}$ at a significance level $\alpha$. In this study, we used a significance level of 0.05 .

\section{Results and Discussion}

\subsection{Homogeneity of Gauging Stations}

The homogeneity test for the 13 stations using the Pettitt test, SNHT, BR test and VNR is presented in Table 2. For each of the test, we fail to reject the null hypothesis when the estimated p-value was greater than the significance level of 0.05 . From Table 2 it is established that none of the test rejected the null hypothesis and hence all stations considered homogenous and falling under class 1 "useful". The homogeneity nature of the stations is an indication that any trend that is observed in the series is truly due to climate and weather variations but not caused by errors in measuring instruments, conditions around station and the methods employed in the data collection (Lazaro et al., 2001; Firat et al., 2010; Kang \& Yusof, 2012; Dhorde \& Zarenistanak, 2013). As all gauges satisfied the homogeneity test, all the 13 stations were used further in the analysis for the long term

\begin{tabular}{|c|c|c|c|c|c|c|}
\hline \multirow{2}{*}{ Station } & \multicolumn{4}{|c|}{ Test Method $^{\mathrm{a}}$} & \multirow{2}{*}{ Class } & \multirow[t]{2}{*}{ Class Description } \\
\hline & $\mathrm{K}$ & SNHT & $\mathrm{Q}$ & $\mathrm{N}$ & & \\
\hline Delmas Vlak & $90(0.67)$ & $2.24(0.81)$ & $3.97(0.70)$ & $2.14(0.68)$ & 1 & Useful \\
\hline Morgenzon & $132(0.24)$ & $4.78(0.34)$ & $5.31(0.34)$ & $1.53(0.06)$ & 1 & Useful \\
\hline Rus-de-winte & $126(0.29)$ & $3.24(0.59)$ & $5.25(0.36)$ & $2.20(0.73)$ & 1 & Useful \\
\hline Rustplaats & $160(0.09)$ & $5.17(0.28)$ & $5.27(0.36)$ & $1.55(0.07)$ & 1 & Useful \\
\hline Marble Hall & $140(0.19)$ & $4.82(0.26)$ & $6.19(0.21)$ & $2.13(0.66)$ & 1 & Useful \\
\hline Ohrigstad & $116(0.38)$ & $1.52(0.93)$ & $2.95(0.93)$ & $2.29(0.83)$ & 1 & Useful \\
\hline Oudestad & $126(0.29)$ & $8.24(0.09)$ & $6.61(0.13)$ & $1.72(0.18)$ & 1 & Useful \\
\hline Loskop & $116(0.38)$ & $2.82(0.65)$ & $4.95(0.43)$ & $1.91(0.38)$ & 1 & Useful \\
\hline Rus-de-winte & $140(0.19)$ & $2.87(0.65)$ & $4.89(0.44)$ & $2.02(0.52)$ & 1 & Useful \\
\hline Roossenekal & $138(0.17)$ & $6.25(0.12)$ & $6.87(0.11)$ & $1.93(0.42)$ & 1 & Useful \\
\hline Buffelskloof & $88(0.70)$ & $2.22(0.80)$ & $4.70(0.50)$ & $1.90(0.37)$ & 1 & Useful \\
\hline Blyderiv & $112(0.43)$ & $4.72(0.29)$ & $4.51(0.55)$ & $1.86(0.34)$ & 1 & Useful \\
\hline
\end{tabular}
rainfall trend for the period $1975-2013$.

Table 2. Homogeneity test for 13 selected stations for the period 1975-2013

${ }^{a}$ K - Pettitt Test; SNHT - Standard Normal Homogeneity Test; Q - Buishands Range Test; N - Von Neumann Ratio Test.

Notes. Figures in bracket represent p-values at the significance level of 0.05 .

\subsection{Annual Rainfall Characteristics}

Presented in Table 3 are the annual rainfall characteristics of the Olifants Basin for the period 1975-2013. Mean annual rainfall is $664 \mathrm{~mm}$ with a standard deviation of $156.4 \mathrm{~mm}$. Mean annual rainfall obtained in this work 
closely agrees with that estimated $(630 \mathrm{~mm})$ by Schulze et al. (1997). Apparently, the differences in the mean annual rainfall obtained in this work compared to that of Schulze et al. (1997) may probably be due to the long span of data used in this study whose results captures the long term rainfall characteristic. However, the mean annual rainfall for the basin is higher than the national mean annual rainfall of $495 \mathrm{~mm}$ (Tadross \& Johnston, 2012). Mean values of the coefficient of variation $\left(C_{v}\right)$, coefficient of skewness $(C s)$, coefficient of kurtosis $\left(C_{k}\right)$ for the Olifants Basin were $24 \%, 0.19$ and 0.32 respectively. For all stations $\mathrm{Cv}$ was higher than $20 \%$ with the exception of Rus-de-winter_DWA station (19.41\%). In their study, McCartney and Arranz (2007) found the Cv for the Olifants Basin to be in the order of $25 \%$ which agrees well with the $24 \%$ recorded in this study. These indexes demonstrate high rainfall variability within the Olifants Basin as already reported by McCartney and Arranz (2007). Out of the 13 studied stations, the Morgenzon station recorded the highest mean annual rainfall of $1023.2 \mathrm{~mm}$ with a standard deviation of $249.4 \mathrm{~mm}$. According to Schulze et al. (1997) the orographic characteristics within the region of the escarpment where the Morgenzon station is located causes the occurrence of the high rainfall amount with mean annual rainfall exceeding 1,000 $\mathrm{mm}$. The mean annual rainfall for all stations ranged from a minimum of $74.3 \mathrm{~mm}$ at Oudestad station to a maximum of $1618.4 \mathrm{~mm}$ at Morgenzon gauge station. A spatial analysis of the rainfall pattern revealed the southern portion of the basin as receiving more rainfall compared to the northern portion. Although generally the rainfall for all stations follows a somewhat similar pattern (Fig. 2), records of the Morgenzon station are high for the years under consideration. This affirms the orographic influences on rainfall within that region of the Olifants Basin.

Table 3. Temporal statistics of rainfall for the period 1975-2013 for the Olifants Basin

\begin{tabular}{lccccccc}
\hline \multirow{2}{*}{ Station } & \multicolumn{7}{c}{ Statistics } \\
\cline { 2 - 8 } Delmas Vlakplaas & $\mathrm{R}_{\min }(\mathrm{mm})$ & $\mathrm{R}_{\max }(\mathrm{mm})$ & $\mathrm{R}_{\mathrm{m}}(\mathrm{mm})$ & $\mathrm{SD}(\mathrm{mm})$ & $\mathrm{C}_{\mathrm{v}}(\%)$ & $\mathrm{C}_{\mathrm{s}}$ & $\mathrm{C}_{\mathrm{k}}$ \\
\cline { 2 - 8 } Morgenzon & 455.30 & 1159.30 & 700.34 & 148.66 & 21.23 & 0.70 & 0.75 \\
Rus-de-winter(SAWS) & 405.00 & 1618.40 & $\mathbf{1 0 2 3 . 1 8}$ & 249.37 & 24.37 & -0.30 & 0.33 \\
Rustplaats & 257.10 & 955.50 & 608.15 & 142.85 & 23.49 & -0.06 & 0.16 \\
Marble Hall & 281.30 & 1071.10 & 618.69 & 157.64 & 25.48 & 0.53 & 1.22 \\
Ohrigstad & 345.00 & 816.40 & 559.70 & 147.89 & 26.42 & 0.25 & -1.20 \\
Oudestad & 322.20 & 959.00 & 571.57 & 131.00 & 22.92 & 0.87 & 1.49 \\
Loskop & 74.33 & 822.20 & $\mathbf{5 5 4 . 0 7}$ & 146.24 & 26.39 & -0.97 & 1.63 \\
Rus-de-winter(DWA) & 240.50 & 990.80 & 639.68 & 157.22 & 24.58 & -0.03 & 0.01 \\
Roossenekal & 387.87 & 898.27 & 630.36 & 122.33 & 19.41 & 0.08 & -0.53 \\
Buffelskloof & 317.30 & 1054.93 & 702.30 & 165.79 & 23.61 & -0.32 & -0.18 \\
Blyderiv & 449.40 & 1068.00 & 691.02 & 148.44 & 21.48 & 0.59 & 0.09 \\
Groenfontein & 344.50 & 1061.10 & 591.77 & 163.70 & 27.66 & 0.67 & 0.12 \\
Olifants Basin & 462.900 & 1162.810 & 740.708 & 151.609 & 20.47 & 0.470 & 0.275 \\
& $\mathbf{3 3 4 . 0 5}$ & $\mathbf{1 0 4 9 . 0 6}$ & $\mathbf{6 6 3 . 9 6}$ & $\mathbf{1 5 6 . 3 6}$ & $\mathbf{2 4 . 0 0}$ & $\mathbf{0 . 1 9}$ & $\mathbf{0 . 3 2}$ \\
\hline
\end{tabular}

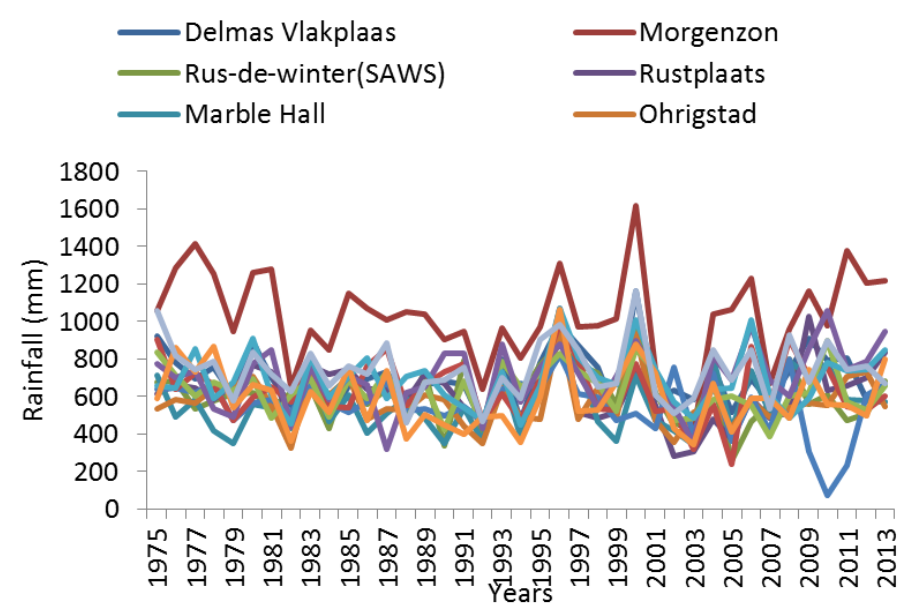

Figure 2. Comparison of mean annual rainfall for 13 stations in the Olifants Basin 


\subsection{Annual Rainfall Trend}

The results of the non-parametric MK test are shown in Table 4 with all stations showing an insignificant trend. The mean annual rainfall for the Olifants Basin exhibits an insignificant decreasing trend of $0.07 \mathrm{~mm} /$ year. However, according to Daniel, (1978) a statistically significant trend may not be practically significant and vice versa. The insignificant trend observed in all stations could be attributed to a number of reasons, one being non-availability of century scale data for the selected stations (Zarenistanak et al., 2014). The insignificant trend detected in this work does not differ from findings of other studies such as that carried out by Raziei (2008) and Shifteh Somme et al (2012). A decreasing insignificant trend in rainfall has also been reported in South Africa and especially in the northeastern part of the country where the basin is located (Jury, 2013; MacKellar et al., 2014). There is little evidence of significant long term trends in annual rainfall generally over South Africa (Mason et al., 1999). According to other studies (Hulme, 1996; Mason \& Jury, 1997; Jury \& Majodina, 1997; Hense et al., 1998) annual rainfall totals decreased in areas where atmospheric pressure was observed decreasing. Fig. 3 shows the aggregated annual rainfall for all the 13 stations. From the plot it is observed that high rainfall peaks were observed in the year 1995 and 2000 which decreased in the year 2003. On station wise basis, 10 out of the 13 stations indicated a decreasing trend in rainfall pattern with Marble Hall, Roossenekal and Buffelskloof stations recording increase in rainfall (Fig. 4 and 5). The magnitudes of annual rainfall increase were 0.04 $\mathrm{mm} /$ year, $0.14 \mathrm{~mm} /$ year and $0.19 \mathrm{~mm} /$ year respectively for Buffelskloof, Marble Hall and Roossenekal stations.

Interestingly, all the three stations showing increase in rainfall are located within the middle section of the Olifants Basin. Deductions made, therefore, conclude that the middle portion of the Olifants Basin receives much rain compared to the other parts of the basin. Although from the MK test the changes observed are insignificant, it is crucial to acknowledge that some changes have occurred over the years. The changes that have occurred can best be explained by the on-going global warming- climate change nexus.

Table 4. Rainfall trends from 1975 to 2013

\begin{tabular}{lccc}
\hline Station & P-value & $\mathrm{Z}_{\mathrm{MK}}$ & Sens slope \\
\hline Delmas Vlakplaas & 0.98 & -0.04 & -0.09 \\
Morgenzon & 0.68 & -0.05 & -1.17 \\
Rus-de-winter(SAWS) & 0.65 & -0.05 & -0.75 \\
Rustplaats & 0.21 & -0.14 & -2.65 \\
Marble Hall & 0.23 & 0.14 & $\mathbf{2 . 7 4}$ \\
Ohrigstad & 0.65 & -0.05 & -0.64 \\
Oudestad & 0.12 & -0.18 & -3.86 \\
Loskop & 0.31 & -0.12 & -1.60 \\
Rus-de-winter(DWA) & 0.35 & -0.11 & -1.74 \\
Roossenekal & 0.09 & 0.19 & $\mathbf{4 . 6 8}$ \\
Buffelskloof & 0.76 & 0.04 & $\mathbf{0 . 7 2}$ \\
Blyderiv & 0.57 & -0.07 & -1.59 \\
Groenfontein & 0.76 & -0.04 & -0.85 \\
\hline
\end{tabular}

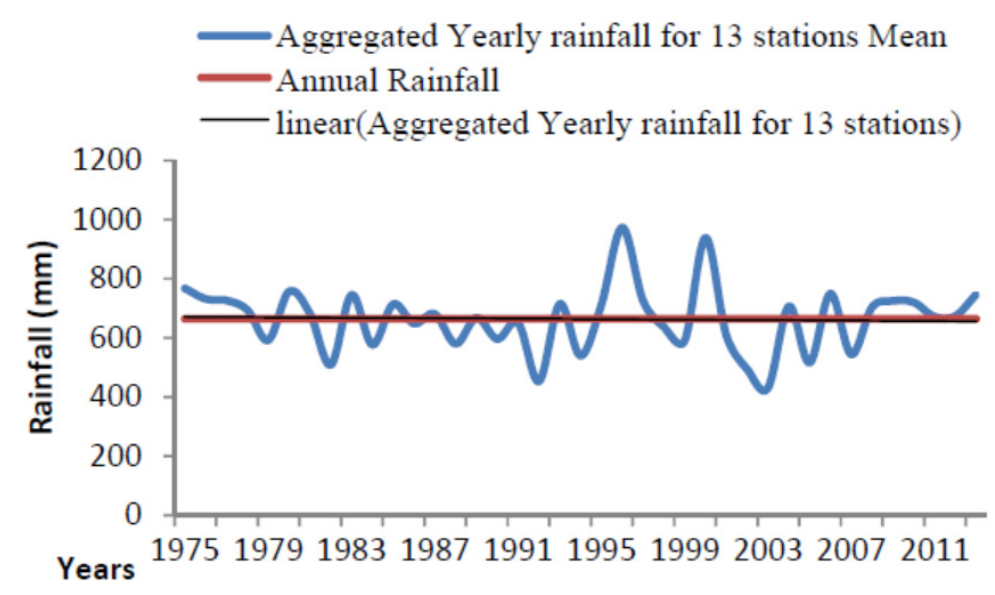

Figure 3. Annual rainfall variation in the Olifants Basin 

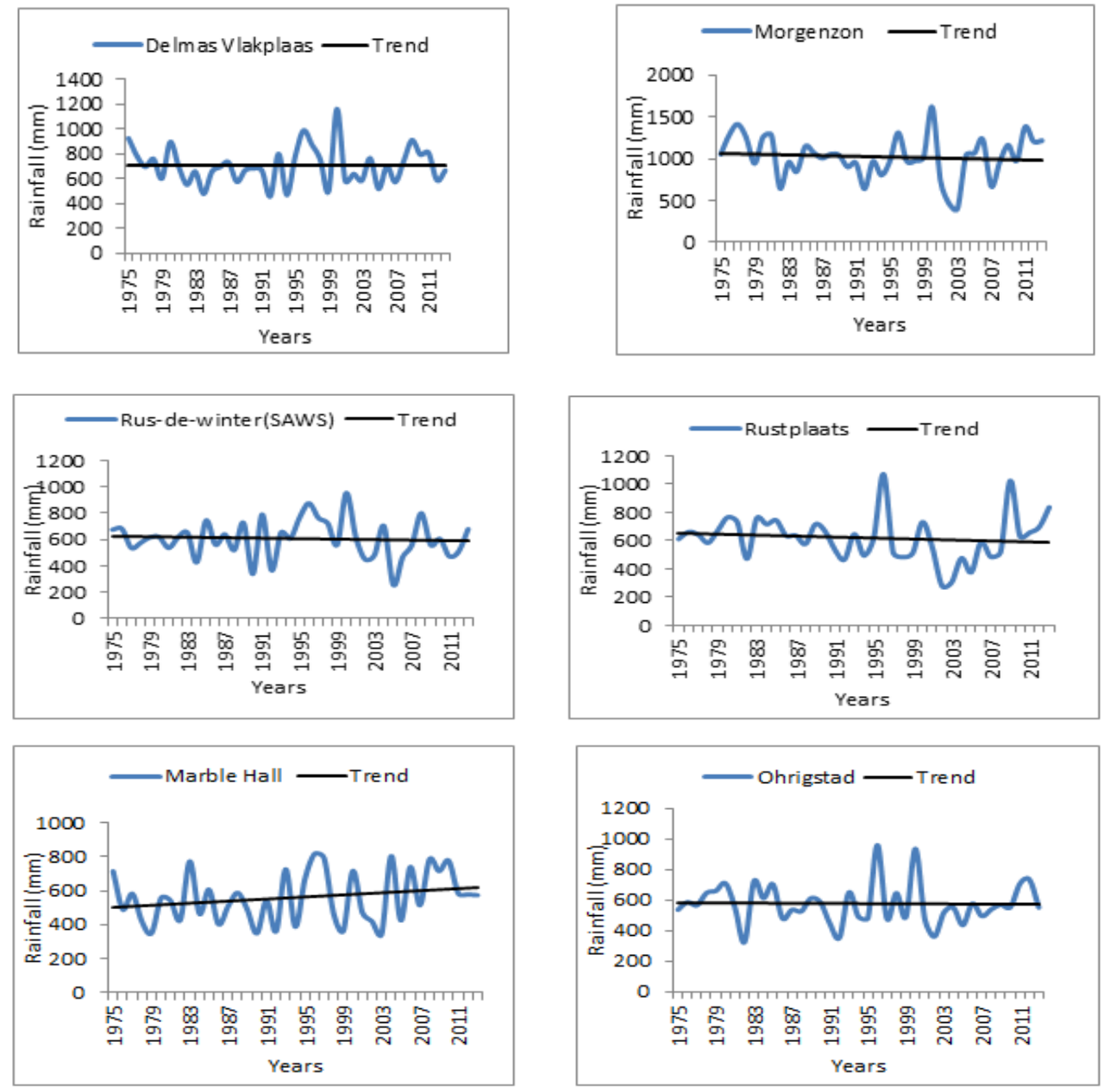

Figure 4. Annual temporal variation in rainfall for Delmas vlakplaas, Morgenzon, Rus-de-winter, Rustplaats, Marble Hall and Ohrigstad stations
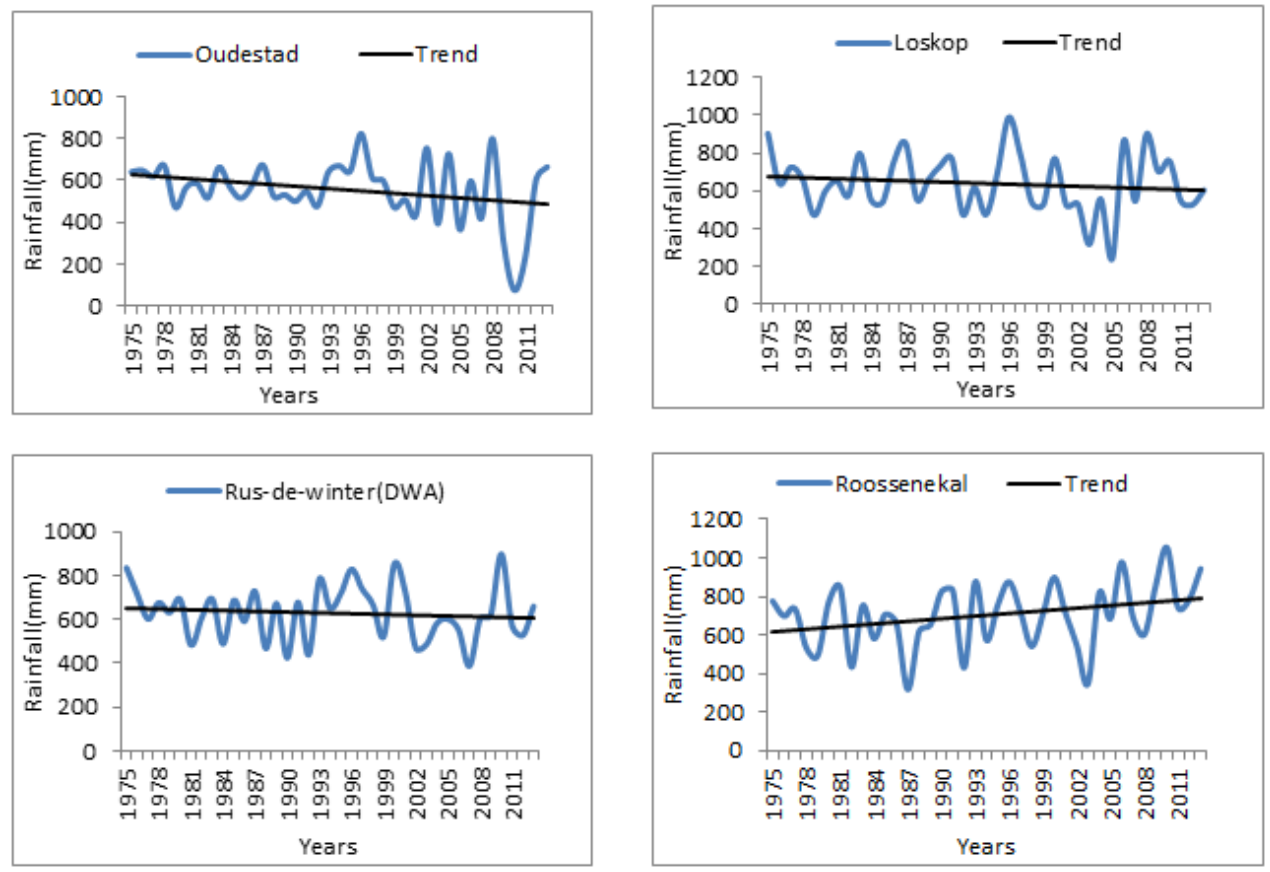

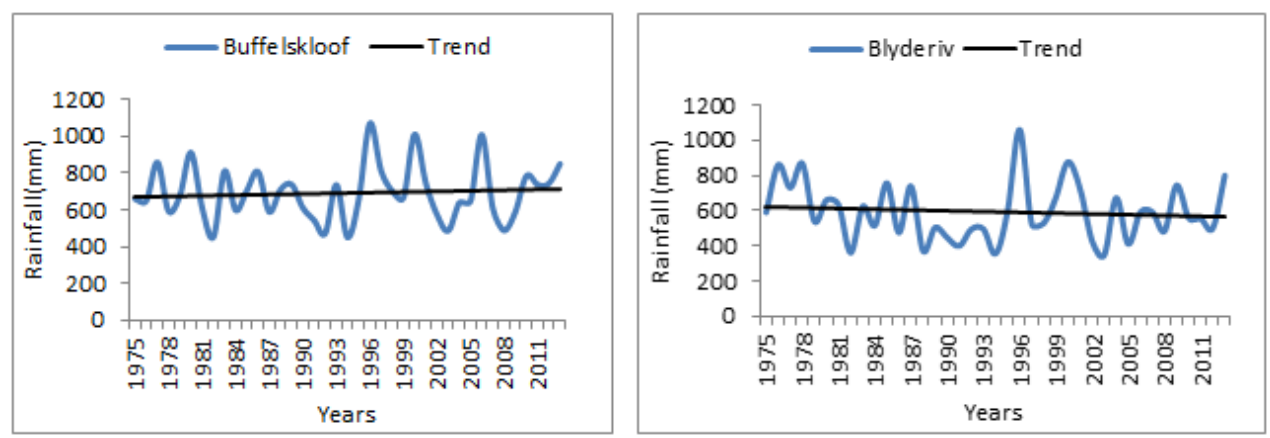

Figure 5. Annual temporal variation in rainfall for Delmas vlakplaas, Morgenzon, Rus-de-winter, Rustplaats, Marble Hall and Ohrigstad stations

\subsection{Seasonal Trend}

\subsubsection{Summer (December - February)}

The greatest proportion of rainfall occurring in the basin and for South African as whole occurs predominantly during the summer season. Findings of this study show an annual rainfall decline of $0.05 \mathrm{~mm}$ for the summer season with the long term annual ranging from $51.0 \mathrm{~mm}$ to $189.8 \mathrm{~mm}$. From Fig. 6 it is clear that the period between 1981 and 1995 experienced a marked decrease in rainfall as indicated by the 5 year moving average and the trend line. During the period 1996 - 2001, rainfall in summer increased and eventually declined again in 2004. A comparison of the periods; 1981-1995 and 1996-2001 indicates 14 years decline period as opposed to the 5 years of rainfall increment. Although rainfall amount in summer may turn to increase, the rate of decline in rainfall during this season is expected to exceed that of increment. An implication of this is the survival of subsistence farming systems within the basin which rely on rainfall for their farming activities. From the water resources point of view, the declining trend in rainfall will affect available water resources through the rainfall-runoff relationship. This observation is also shared by Hartkamp et al. (1999) where they attested to the spatial and temporal variability consequences on water resources management and agriculture systems. On a monthly analysis, rainfall occurring in January and February declined at rates of $0.03 \mathrm{~mm} / \mathrm{year}$ and $0.12 \mathrm{~mm} / \mathrm{year}$ respectively. However December received an increase in rainfall to the tune of $0.09 \mathrm{~mm} / \mathrm{year}$. The falling trend in summer rainfall is due to the monthly declines experienced in January and February.

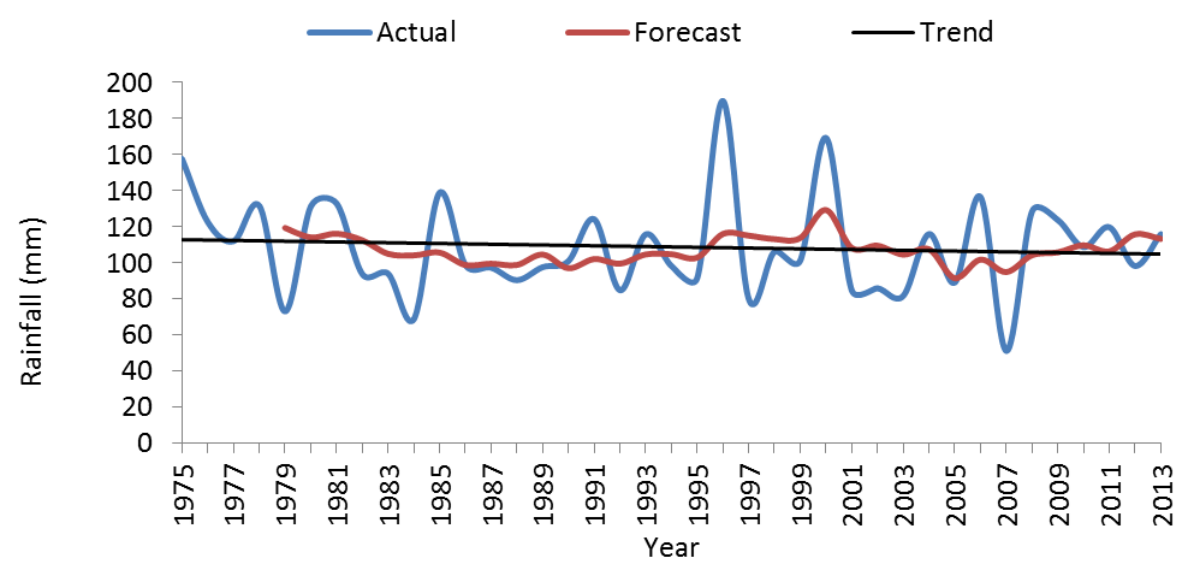

Figure 6. Temporal rainfall trend for summer for the period 1975-2013

\subsubsection{Autumn (March - May)}

The MK test indicated an insignificant increase in rainfall during autumn season at a rate of $0.01 \mathrm{~mm} / \mathrm{year}$. The long term minimum and maximum rainfall during autumn were $17.2 \mathrm{~mm}$ and $79.9 \mathrm{~mm}$ respectively. Shown in Fig. 7 is the temporal variation of rainfall for the autumn season for the period under review. On comparing the 5 
year moving average with the trend line, there was a decline in rainfall between the periods 1980-1995 and 2001-2010. However the period 1995-2001 received an increase in rainfall. Although rainfall declined during most of the period 1975-2013, this did not cause a total rainfall trend decline for the season. The first section of the declining period for both autumn and summer fairly occurred around the same time period of 1980-1995 and the 1996-2001 increment periods also common to both seasons. Nonetheless, the decline of rainfall in the period 2001-2010 is only peculiar to the autumn season. Monthly wise, rainfall in April and May increased at $0.05 \mathrm{~mm} /$ year and $0.10 \mathrm{~mm} /$ year respectively. In March, rainfall received a decline of $0.134 \mathrm{~mm} /$ year. Rainfall therefore increased in two out of the three months that constitutes the autumn season.

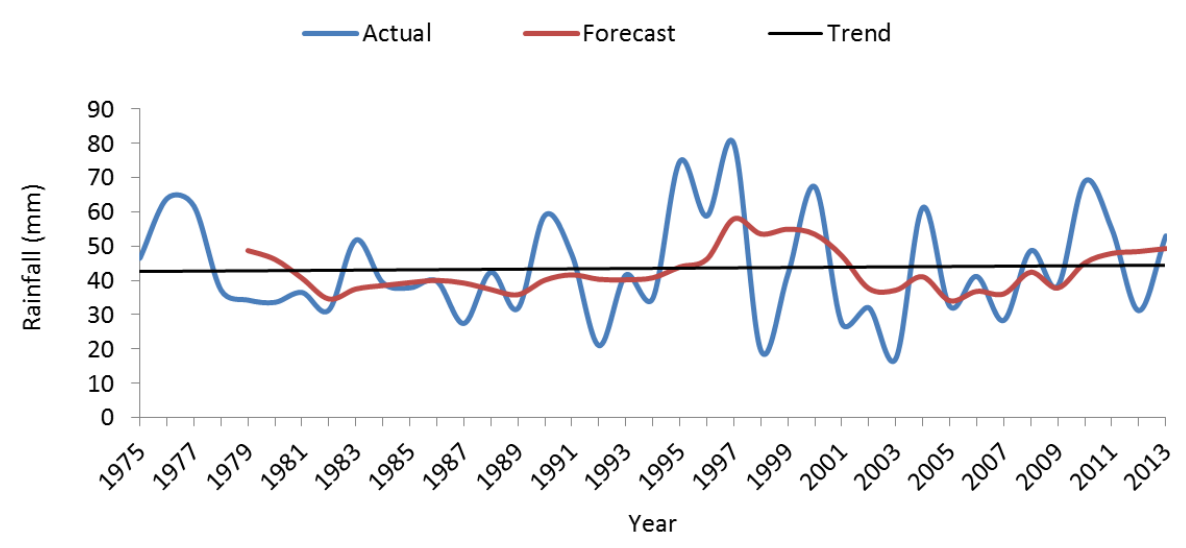

Figure 7. Temporal rainfall trend for autumn for the period 1975-2013

\subsubsection{Spring (September - November)}

A decreasing trend was found during the spring season with long term rainfall ranging $36.4 \mathrm{~mm}-95.1 \mathrm{~mm}$. During 1985-1989 and 1995-2001 there was an increase in rainfall. On the contrary rainfall declined during 1989-1995 and 2001-2008. Unlike summer and autumn, rainfall in spring increased and declined for two different time periods. Rainfall decreased in September and October at rate of $0.012 \mathrm{~mm} /$ year and $0.01 \mathrm{~mm} /$ year respectively.

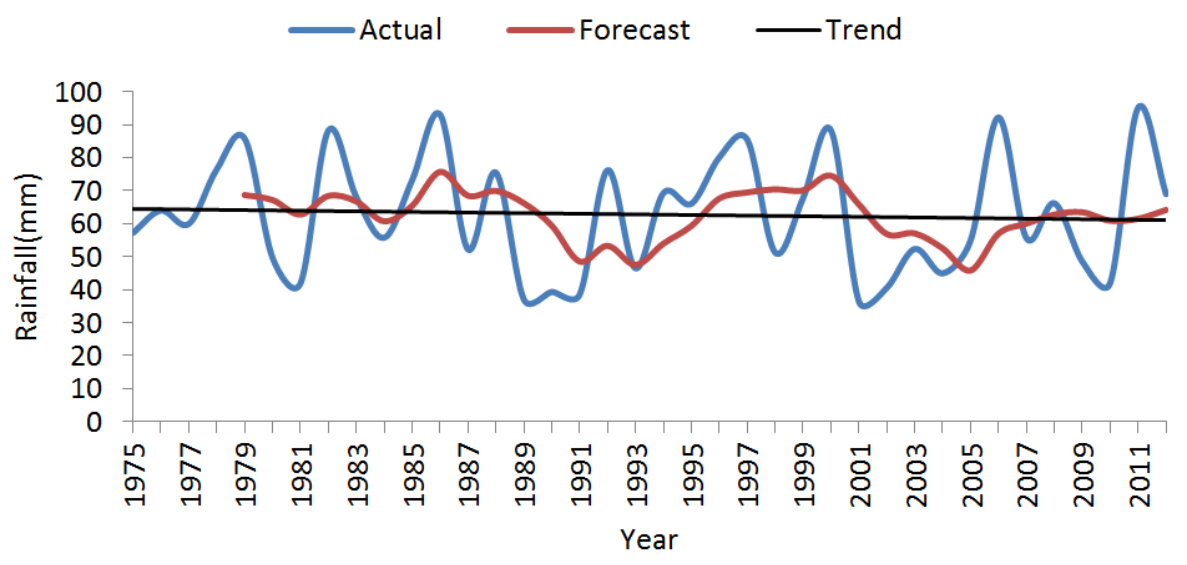

Figure 8. Temporal rainfall trend for spring for the period 1975-2013

\section{Conclusion}

Homogeneity and trend analysis were the focus of the study. All 13 stations used were found to be homogenous and subsequently used in the trend analysis. Generally rainfall in the Olifants Basin declined during the period under review (1975-2013) with a mean annual rainfall of $664 \mathrm{~mm}$. However, the decline cannot be said to be significant. Spatio-temporal variations of rainfall were also noted as depicted by the overall coefficient of variation of $24 \%$. Rainfall in the middle portion of the basin increased compared to the decline in the remaining parts of the basin. Inter-annual and seasonal variability characterized the historical rainfall records of the area. 
Rainfall in the months of January, February, March, September and October declined whiles that of April, May, November and December increased over the 39 year period. The declining trend in rainfall can only be attributed to the changes in climate that has occurred over the years. Implications of the findings are enormous on (i) agriculture and (ii) water resources planning and management. Subsistence farmers who depend on rainfall must acknowledge the changing patterns in rainfall and adopt accordingly in order to safe guard against crop failure. Water resources of the basin through rainfall-runoff relationship stands to suffer some repercussions; as a result management strategies should be implemented to ensure the judicious use of available water resources. Findings from this study is hoped to present a fundamental basis for the local climate change scientific community whose efforts are in the area of Global Circulation models (GCMs) applications in climate change studies.

\section{Acknowledgement}

Our gratitude goes to Tshwane University of Technology for financially supporting this study. We also wish to extend our profound appreciation to South African Weather Service (SAWS) and the Department of Water Affairs for freely availing the data used for the study.

\section{References}

Alexanderson, H. A. (1986). A homogeneity test applied to precipitation data. Journal of Climatology, 6, 661-675.

Barnett, J., \& Adger, W. N. (2007). Climate change, human security and violent conflict. Political Geography, 26, 639-655. http://dx.doi.org/10.1016/j.polgeo.2007.03.003

Buishand, T. A. (1982). Some Methods for Testing the Homogeneity of Rainfall Records. Journal of Hydrology, $58,11-27$.

Christensen, N. S., \& Lettenmaier, D. P. (2000). A multimodel ensemble approach to assessment of climate change impacts on the hydrology and water resources of the Colorado River Basin. Hydrological and Earth System Science, 11, 1417-1434. http://dx.doi.org/10.5194/hess-11-1417-2007

Costa, A. C., \& Soares, A. (2009). Homogenization of climate data: Review and new perspectives using geostatistics. Mathematical Geoscience, 41, 291-305.

Daniel, W. W. (1978). Applied nonparametric statistics. Houghton Mifflin Comp, Boston.

Dhorde, A. G., \& Zarenistanak, M. (2013). Three-way approach to test data homogeneity: An analysis of temperature and precipitation series over southwestern Islamic Republic of Iran. Journal of Indian Geophysics Union, 17(3), 233-242.

DWAF. (2004). Olifants Water Management Area: Internal Strategic Perspective. Prepared by GMKS, Tlou and Matji on behalf of the Directorate, Water Resources Planning. DWAF Report No. P WMA 04/000/00/0304 Pretoria: DWAF.

Gong, D. Y., Shi, P. J., \& Wang. J. A. (2004). Daily precipitation changes in the semi-arid region over northern China. Journal of Arid Environments, 59, 771-784

Haddeland, I., Heinke, J., Biemans, H., Eisner, S., Florke, M., Hanasaki, N., ... Wisser, D. (2014). Global water resources affected by human interventions and climate change. Proceedings of the National Academy of Sciences, 111(9), 3251-3256. http://dx.doi.org/10.1073/pnas.1222475110

Hartkamp, A. D., De Beurs, K., Stein, A., \& White, J. W. (1999). Interpolation Techniques for Climate Variables. NRG-GIS Series 99-01. Mexico, D.F.: CIMMYT.

Hense, A., Krahe, P., \& Flohn, H. (1988). Recent Fluctuations of Tropospheric Temperature and Water Vapour Content in the Tropics. Meteorology and Atmospheric Physics, 38, 215-227.

Hulme, M. (1996). Recent Climatic Change in the World's Drylands. Geophysical Research Letters, 23, 61-64.

IPCC. (2014). Climate Change 2014 Synthesis Report. Summary for Policymakers.

IWMI. (2008). Baseline Report Olifants River Basin in South Africa: A contribution to the Challenge Program Project 17 "Integrated Water Resource Management for Improved Rural Livelihoods: Managing risk, mitigating drought and improving water productivity in the water scarce Limpopo Basin"

Jury, M. R. (2013). Climate trends in Southern Africa. South African Journal of science, 109, 1-11. http://dx.doi.org /10.1590/sajs.2013/980

Jury, M. R., \& Majodina, M. (1997). Preliminary Climatology of Southern Africa Extreme Events. Theoretical and Applied Climatology, 56, 89-101. 
Kang, H. M., \& Yusof, F. (2012). Homogeneity Tests on Daily Rainfall Series in Peninsular Malaysia. International Journal of Contemporary Mathematical Sciences 7(1), 9-22.

Karmeshu, N. (2012). Trend Detection in Annual Temperature and Precipitation using the Mann Kendall TestA Case Study to Assess Climate Change on Select States in the Northeastern United States. Master of Environmental Studies Capstone Projects Department of Earth and Environmental Science University of Pennsylvania.

Kendall, M. G. (1948). Rank Correlation Methods. Hafer: New York

Lazaro, R., Rodrigo, F. S., Gutierrez, L., Domingo, F., \& Puigdefabregas, J. (2001). Analysis of a 30-year rainfall record (1967-1997) in semiarid SE Spain for implications on vegetation. Journal of Arid Environments, 48, 373-395.

MacKellar, N., New, M., \& Jack, C. (2014). Observed and modelled trends in rainfall and temperature for South Africa: 1960-2010. South African Journal of science, 110, 1-13. http://dx.doi.org/10.1590/sajs. 2014/20130353

Mann, H. B. (1945). Non-parametric test against trend. Econometrika, 13, 245-259.

Mason, S. J., \& Jury, M. R. (1997). Climatic Variability and Change over Southern Africa: A Reflection on Underlying Processes. Progress in Physical Geography, 21, 23-50

Mason, S. J., Waylen, P. R., Mimmack, G. M., Rajaratnam, B., \& Harrison, J. M. (1999). Changes in Extreme Rainfall Events in South Africa. Climatic Change, 41, 249-257

McCartney, M. P., \& Arranz, R. (2007). Evaluation of historic, current and future demand in the Olifants River catchment, South Africa. International Water Management Institute, Colombo, Sri Lanka (IWMI Research Report 118).

Modarres, R., \& Rodrigues da Silva, V. (2007). Rainfall trends in arid and semi-arid regions of Iran. Journal of Arid Environments, 70, 344-355.

Mourato, S., Moreira, M., \& Corte Real, J. (2010). Interannual variability of precipitation distribution patterns in Southern Portugal. International Journal of Climatology, 30, 1784-1794.

Nasri, M., \& Modarres, R. (2009). Dry spell trend analysis of Isfahan Province, Iran. International Journal of Climatology, 29, 1430-1438.

NRDC. (2010). Climate change and water resources management: Adaptation strategies for protecting people and the environment. Retrieved from http://www.nrdc.org/water/files/waterandclimate.pdf

Patra, J. P., Mishra, A., Singh, R., \& Raghuwanshi, N. S. (2012). Detecting rainfall trends in twentieth century (1871-2006) over Orissa State, India. Climate Change, 111, 801-817. http://dx.doi.org/10.1007/s110584-011-0215-5

Pettitt, A. N. (1979). A non-parametric approach to the change point problem. Journal of Applied Statistics, 28, 126-135.

Piao, S., Ciais, P., Huang, Y., Shen, Z., Peng, S., Li, J., ... Fang, J. (2010). The impacts of climate change on water resources and agriculture in China. Nature, 467, 43-51. http://dx.doi.org/10.1038/nature09364

Prudhomme, C., Giuntoli, I., Robinson, E. L., Clark, D. B., Arnell, N. W., Dankers, R., ... Wisser, D. (2014). Hydrological droughts in the $21^{\text {st }}$ century, hotspots and uncertainties from a global multimodel ensemble experiment. Proceedings of the National Academy of Sciences, 111(9), 3262-3267. http://dx.doi.org/10.1073/pnas.1222473110

Raziei, T. (2008). Investigation of annual precipitation trends inhomogeneous precipitation sub-divisions of western Iran. BALWOIS 2008 - Ohrid, Republic of Macedonia.

Santosh, F. B., \& Ramesh, H. (2013). Analysis of South West monsoon rainfall trend using statistical techniques over Nethravathi Basin. International Journal of Advanced Technology in Civil Engineering, 2(1), 130-136.

Schonwiese, C. D., \& Rapp, J. (1997). Climate trend atlas of Europe based on observation 1891-1990. International Journal of Climatology, 18, 580-598.

Schultz, C. B., \& Watson, M. D. (2002). WSAM: Water Situation Assessment Model-Version 3: A decision support system for reconnaissance level planning. Volume 1: Theoretical Guide. Republic of South Africa: ARCUS-GIBB and DWAF. 
Schulze, R. E., Maharaj, M., Lynch, S. D., Howe, B. J., \& Melvil Thomson, B. (1997). South African Atlas for Agrohydrology and Climatology. University of Natal, Pietermaritzburg.

Shifteh Somee, B., Ezani, A., \& Tabari, H. (2012). Spatiotemporal trends and change point of precipitation in Iran. Atmospheric Research, 113, 1-12.

Smith, L. C. (2000). Trends in Russian Arctic river-ice formation and breakup, 1917 to 1994. Physical Geography, 20(1), 46-56.

Tadross, M., \& Johnston, P. (2012). Climate Systems Regional Report: Southern Africa. ISBN: 978-0-9921794-6-5.

Valipour, M. (2015). Assessment of important factors for water resources management in European Agriculture. Journal of Water Resources and Hydraulic Engineering, 4(2), 171-180.

Valipour, M. (2012). Hydro-Module determination for Vanaei Village in Eslam Abad Gharb, Iran. ARPN Journal of Agricultural and Biological Sciences, 7(12), 968-976.

Valipour, M. (2013a). Use of surface water supply index to assessing of water resources management in Colorado and Oregon, US. Advances in Agriculture, Sciences and Engineering Research, 3(2), 631-640.

Valipour, M. (2013b). Estimation of surface water supply index using Snow Water Equivalent. Advances in Agriculture, Sciences and Engineering Research, 3(1), 587- 602.

Wijngaard, J. B., Klein, T. M., \& Konnen, G. P. (2003). Homogeneity of 20th century European daily temperature and precipitation series. International Journal of Climatology, 23, 679-692.

Zarenistanak, M., Dhorde, M. G., \& Kripalani, R. H. (2014). Trend analysis and change point detection of annual and seasonal precipitation and temperature series over southwest Iran. Journal of Earth System Science, 123(2), 281-295.

Zhang, X., Vincent, L. A., Hogg, W. D., \& Niitsoo, A. (2000). Temperature and precipitation trends in Canada during the $20^{\text {th }}$ century. Atmospheric Ocean, 38, 395-429.

\section{Copyrights}

Copyright for this article is retained by the author(s), with first publication rights granted to the journal.

This is an open-access article distributed under the terms and conditions of the Creative Commons Attribution license (http://creativecommons.org/licenses/by/3.0/). 